\title{
Characterization of victims of aggression and transportation accidents treated at the Forensic Medicine and Dentistry Institute \\ - Campina Grande, Paraíba, Brazil - 2010
}

\author{
Sergio d'Avila ${ }^{1}$ \\ Ana Cristina Campos ${ }^{2}$ \\ Gigliana Maria Sobral Cavalcante ${ }^{2}$ \\ Carlos Jose de Paula Silva ${ }^{2}$ \\ Lorena Marques da Nóbrega ${ }^{1}$ \\ Efigenia Ferreira e Ferreira ${ }^{2}$
}

${ }^{1}$ Departamento de Odontologia, Universidade Estadual da Paraíba. R. Juvêncio Arruda s/n, Bodocongo. 58430-800 Campina Grande PB Brasil. davila2407@hotmail.com ${ }^{2}$ Departamento de Odontologia Social e Preventiva, Faculdade de Odontologia, Universidade Federal de Minas Gerais.

\begin{abstract}
The objective of this cross-sectional census study was to characterize agression and land-based transport accidents in a city in the Northeast of Brazil. Data was analyzed from live victims who were treated at a forensic service ( $N$ $=2.379$ ). In the descriptive analysis, the majority of events were represented by aggression (71.6\%); which occurred on weekdays (65\%), with $35.1 \%$ at night. Trauma occurred to the whole body (63.6\%) and to soft tissue (74.2\%). On the basis of multiple correspondence analysis, two dimensions were formed: the first dimension (internal reliability $=0.654$ ) was formed by the cause of the event, the trauma and the age group and the second dimension (reliability $=0.514$ ), by age group, occupation and civil status. Three groups with distinct profiles were formed for accidents and aggression: young women who suffered aggression, with trauma to the face and soft tissues during the evening and at weekends; adult men who suffered car accidents, in the morning and on work days; and retired elderly widowers, who were run over.
\end{abstract} Key words Violence, External causes, Morbidity 


\section{Introduction}

When the World Health Organization (WHO) drew up the International Classification of Diseases (ICD-10), it designated deaths and complications due to trauma, wounds or any other adverse impacts on health as "external causes", whether these were intentional or not. This group includes injuries caused by mechanical, chemical, thermal actions, electrical energy and/or radiation ${ }^{1}$.

Accidents may be categorized as: land-based transportation accidents (LTA), (involving pedestrians, motorcyclists and passengers in vehicles), falls and other accidents. Violence may consist of aggression and legal interventions as well as actions which are deliberately self-inflicted ${ }^{1}$.

Events due to accidents and aggression are responsible for over 5 million deaths throughout the world every year; it is estimated that for each of these deaths, there are dozens of cases of admission to hospital, hundreds of cases of emergency treatment and thousands of medical consultations; these affect the lives of individuals with sequelae, incapacity for work and expenditure on payment of retirement pensions, allowances and health treatment ${ }^{2}$.

Statistics of studies which evaluate morbidity are not always accurate and in general, the available information is the result of studies on specific populations ${ }^{3}$.

Morbidity due to external causes represents a still incipient field with regard to registers and the availability of information within departments, with the majority of studies conducted on such incidents drawing principally on databases on mortality or admissions to hospital.

Morbidity data are nevertheless regarded as an essential source of information for understanding the magnitude of this phenomenon, its impact on health services and social support networks and for formulating public and health promotion/prevention policies ${ }^{4}$.

One of the current foci of public health with regard to violence is the need to confront the problem through the collection of systemic data from locations where victims of events of violence may be treated, in order to discover its magnitude, its extent, its characteristics and its consequences ${ }^{5}$.

In the face of this scenario, it is perceived that accidents and aggression are incidents of great relevance to epidemiology, in view of the dimension which they occupy in the current context ${ }^{6}$.

In this way, we hope that this study may provide support for studies in this area, given that other investigations are required, due to the increase in cases of treatment for external causes in monitoring and in defining health policies and actions targeting high risk groups.

This study has the objective of characterizing violence through the morbidity data of victims who attended a forensic service to undergo a forensic medical examination as the result of aggression or of a land-based transportation accident.

\section{Methods}

The study was conducted in Campina Grande, Paraíba State, a municipality in the Northeast of Brazil regarded as one of the principal development hubs in the interior of the country, with a human development index of 0.72 ; it forms part of a metropolitan region consisting of 23 municipalities, with an estimated population of 687,545 inhabitants ${ }^{7}$.

The executed design was of cross-sectional census type, with an intentional type sample. An inductive approach was used, through indirect observation, by analyzing the reports of the Legal Medicine and Odontology Group (Numol) for live victims of aggression and land-based transportation accidents of both sexes, who visited the service for a forensic medical examination during the period from January to December 2010. Within the State of Paraíba there are four forensic medicine and odontology groups, with this one ranking second in terms of the number of victims attended.

Data were collected through a form specifically designed for this survey, which contained: the sociodemographic data of the victim (age, sex, marital status, educational level and occupation), cause of the event: accidents (pedestrians, motorcyclists and passengers of vehicles) and aggression and relevant data on the event: cause, day and time, type of injury and affected region of the body.

All records with registers and/or information on accidents and aggression involving individuals resident within the metropolitan area of the study were analyzed, with this amounting to 2,379 records. We excluded records on dead victims, reports due to other types of externally caused morbidity, records with more than three missing data items, records which were considered to be illegible even after consultation of a doctor or dentist of the institution or records which were absent for legal or judicial reasons. 
This study followed the international and national guidelines for research on humans (Helsinki Declaration and Resolution $196 / 96^{\circ}$ of the National Health Council (CNS). It was registered with the Sisnep, forwarded to and approved by the Research Ethics Committee of the State University of Paraíba.

The construction of the database and the analysis were carried out on the Statistical Package of the Social Sciences software application, version 20. A descriptive analysis was initially conducted on all of the variables of the study. We then attempted to explore joint relationships between the socioeconomic and demographic characteristics and the types of LTA and aggression through multiple correspondence analysis.

Multiple correspondence analysis (MCA) was used, an exploratory technique used to analyze categorical data with a large number of variables, with the objective of positioning the response categories within the same system of axes (dimensions) and which has been used to interpret profiles associated with the variables in question; only recently, this type of analysis has been gaining more popularity in the area of health, especially for the study of violence.

Through graphic representation, the positions of categories for each variable on a multi-dimensional plane may be interpreted as associations. Furthermore, MCA permits the profiles of each observed unit (cases) to be established, permitting the evaluation of relationships between these and the analyzed variables. It is useful to study risk factors which may be associated with given characteristics for which analysis is sought, with this also permitting the identification of groups with the same risk factors ${ }^{9,10}$.

The importance of each variable in the construction of axes via discriminating measures and the position of points on the graph assists with the interpretation of results and also contributes to the characterization of the axes in conceptual terms ${ }^{11}$.

The analysis also calculates Cronbach's alpha coefficient for the verification of the internal reliability of the dimensions so formed and for obtaining an appropriate estimate of the magnitude of variance explained by inertia ${ }^{12}$.

\section{Results}

The age of the victims $(\mathrm{n}=2.379)$ varied from 1 to 98 . Table 1 presents the distribution by age, sex, civil status, educational level and occupa- tion. Within this table, we may highlight the fact that sample consisted of individuals aged 30-59 (39.9\%), who were male (56.6\%), single (52.9\%), educated to primary level $(42.1 \%)$ and who were employed at the time of the event $(60.2 \%)$.

In Table 2, we may observe that most events were due to aggression $(71.6 \%)$, followed by accidents with motorcycles $(18.5 \%)$. Bodily injuries occurred in $63.6 \%$ of total cases. Traumas affected soft tissue (74.2\%). Events occurred with greater frequency during weekends $(33.5 \%$ in 2 days) and $35.1 \%$ at night.

Evaluating the data appearing in Table 3, we observe the discrimination measures for each variable in the composition of each dimension. We observe that the first dimension is predominantly formed by the cause of the event (60.9\%), by trauma (58.2\%) and by age group (30.8\%).

The most discriminating variables for victims in forming the second dimension were age group (60.5\%), occupation (57.3\%) and marital status (35\%).

Table 1. Distribution of victims, by socioeconomic and demographic characteristics.

\begin{tabular}{|c|c|c|}
\hline $\begin{array}{l}\text { Variables } \\
\text { Categories }\end{array}$ & $\begin{array}{c}\mathbf{n} \\
2.379\end{array}$ & $\%$ \\
\hline \multicolumn{3}{|l|}{ Age } \\
\hline$\leq 9$ & 42 & 1.8 \\
\hline $10-19$ & 355 & 14.9 \\
\hline $20-29$ & 837 & 35.2 \\
\hline $30-59$ & 949 & 39.9 \\
\hline$\geq 60$ & 196 & 8.2 \\
\hline \multicolumn{3}{|l|}{ Sex } \\
\hline Female & 1032 & 43.4 \\
\hline Male & 1347 & 56.6 \\
\hline \multicolumn{3}{|l|}{ Marital status } \\
\hline Single & 1258 & 52.9 \\
\hline Widowed & 46 & 1.9 \\
\hline Separated & 94 & 4.0 \\
\hline Married or stable union & 849 & 35.7 \\
\hline Unknown & 132 & 5.5 \\
\hline \multicolumn{3}{|l|}{ Education } \\
\hline Illiterate & 130 & 5.5 \\
\hline Primary education & 1001 & 42.1 \\
\hline Secondary education & 407 & 17.1 \\
\hline Higher education & 146 & 6.1 \\
\hline Unknown & 695 & 29.2 \\
\hline \multicolumn{3}{|l|}{ Occupation } \\
\hline Employed/Self-Employed & 1431 & 60.2 \\
\hline Unemployed & 53 & 2.2 \\
\hline Retired & 38 & 1.6 \\
\hline Not Working & 204 & 8.6 \\
\hline Unknown & 653 & 27.4 \\
\hline
\end{tabular}


Table 2. Distribution of victims, by characteristics: types of external cause, region of trauma and of the event.

\begin{tabular}{lrr}
\hline \multicolumn{1}{c}{ Variables } & n & \multicolumn{1}{c}{$\%$} \\
& $\mathbf{2 , 3 7 9}$ & \\
\hline External cause & & \\
LTA - Occupant of vehicle & 135 & 5.7 \\
LTA - Motorcyclist & 439 & 18.5 \\
LTA - Pedestrian & 77 & 3.2 \\
Aggression & 1704 & 71.6 \\
Unknown & 24 & 1.0 \\
Region of trauma & & \\
Facial & 866 & 36.4 \\
Bodily & 1513 & 63.6 \\
Type of trauma & & \\
Simple fracture & 408 & 17.2 \\
Multiple fracture & 84 & 3.5 \\
Soft tissue & 1766 & 74.2 \\
Dento-alveolar & 16 & 0.7 \\
Unknown & 105 & 4.4 \\
Day of the week of occurence & & \\
Working days & 1546 & 65.0 \\
Weekend & 797 & 33.5 \\
$\quad$ Unknown & 36 & 1.5 \\
Time of occurrence & & \\
Early morning & 196 & 8.2 \\
Morning & 447 & 18.8 \\
Evening & 694 & 29.2 \\
Night & 834 & 35.1 \\
Unknown & 208 & 8.7 \\
\hline
\end{tabular}

Table 3. Measures of discrimination for the socioeconomic and demographic characteristics of the victim and of types of violence.

\begin{tabular}{lcr}
\hline \multirow{2}{*}{ Variables } & \multicolumn{2}{c}{ Measures of discrimination } \\
\cline { 2 - 3 } \multicolumn{1}{c}{ Dimension 1 } & Dimension 2 \\
\hline Event & $\mathbf{0 . 6 0 9}$ & 0.029 \\
Trauma & $\mathbf{0 . 5 8 2}$ & 0.002 \\
Age group & $\mathbf{0 . 3 0 8}$ & $\mathbf{0 . 6 0 5}$ \\
Sex & 0.212 & 0.000 \\
Educational level & 0.192 & 0.141 \\
Region of trauma & 0.157 & 0.000 \\
Occupation & 0.139 & $\mathbf{0 . 5 7 3}$ \\
Time & 0.113 & 0.090 \\
Marital status & 0.088 & $\mathbf{0 . 3 5 0}$ \\
Day of the week & 0.033 & 0.071 \\
Eigenvalue & 2.433 & 1.861 \\
Inertia & 0.243 & 0.186 \\
Cronbach's Alpha & 0.654 & 0.514 \\
\hline
\end{tabular}

The results of correspondence analysis showed that the two dimensions explained $42.9 \%$ (eigenvalue) of total variability. Dimension 1 had an internal reliability equal to 0.654 , while the second dimension was 0.514 (Table 3).

Figure 1 shows the graphic representation of the categories of variables in the plane with two dimensions. Three groups were formed with distinct profiles of morbidity data for events.

Young women (aged 20 to 29), who were single or separated, unemployed or inactive, with an educational level above primary level, suffered aggression with trauma to the face and soft tissues during the evening, at night and in the early morning during weekdays.

Conversely, a group was formed which presented bodily trauma with simple and multiple fractures arising from accidents involving the occupants of vehicles, where the event occurred in the morning and on working days. This group essentially consisted of adult men (aged 30 to 59), who were married, employed or self-employed, without education or with an undetermined educational level. The group in the lower left quadrant consists of pedestrians, the elderly, widowers and pensioners, who were run over at an undefined time of the day.

\section{Discussion}

The importance of epidemiological surveys lies in the scope for understanding how a given event manifests itself in the studied population. In dealing with accidents and aggression, analyses must be carried out with a view to the sociodemographic characterization of the exposed individuals.

The number of inhabitants of the metropolitan region encountered in this study reveal the notable consistency with studies of victims of land-based transportation accidents and of aggression treated at the various public health services within Brazil ${ }^{13-15}$.

The individuals who sought the forensic service as a result of land-based transportation accidents were seeking the report in order to claim against insurance policies for personal injuries caused by motor vehicles (DPVAT). This policy is a type of annual contract signed between the State and insurers and is mandatory for owners of motor vehicles, having as its principal aim the compensation of victims of traffic accidents ${ }^{16}$. We can infer that this data item may be more reliable than the data item for aggression, e.g. where 


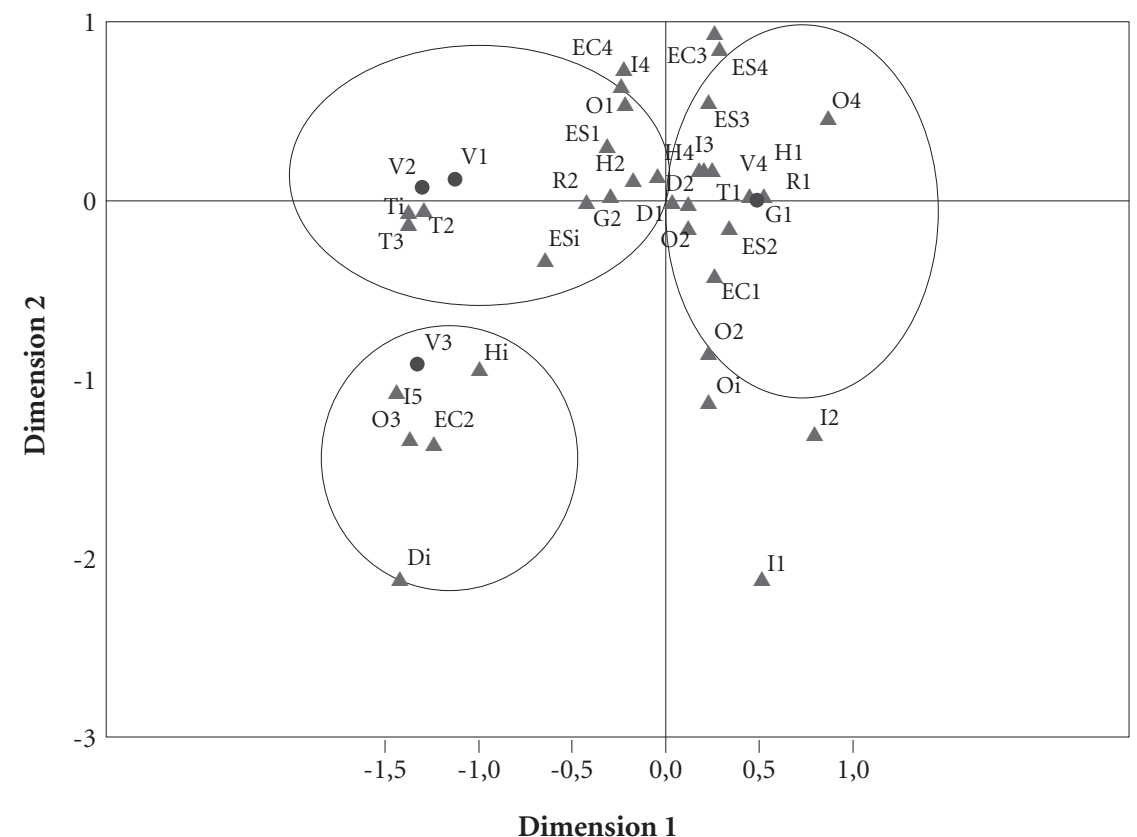

Legend:

I1: $\leq 9$

I2: $10-19$

I3: $20-29$

I4: $30-59$

I5: $\geq 60$

G1: Female

G2: Male

EC1: Single

EC2: Widowed

EC3: Separated
EC4: Married and stable union

ES1: Illiterate

ES2: Primary education

ES3: Secondary education

ES4: Higher education

ES5: Education unknown

O1: Employed/Self-employed

O2: Unemployed

O3: Retired

O4: Not working
O5: Occupation unknown

V1: Car accident

V2: Motorcycle accident

V3: Run over

V4: Aggression

R1: Facial

R2: Bodily

T1: Soft tissue

T2: Simple fracture

T3: Multiple fracture
T4: Dentoalveolar

T5: Trauma unknown

D1: Weekdays

D2: Weekends

H1: Early morning

H2: Morning

H3: Evening

H4: Night

H5: Time unknown

Figure 1. Categories of types of violence and socioeconomic and demographic characteristics resulting from the correspondance analysis for two dimensions.

there is no compensation, in addition to the fact that a constraint frequently occurs.

The majority of the sample consisted of men aged 30 to 59 , corresponding to the productive age group, with such results also observed in other studies ${ }^{13,14,17-19}$. Single men were the most frequently involved in events, with the majority having completed primary education ${ }^{11,15,20}$. A notable fact is that at the time when the accident occurred, the subjects of the survey were employed ${ }^{15,20}$ a situation which, depending on its severity, may lead to inability to work.

The low educational level of participants in the study was a reflection of the socioeconomic conditions of the studied region, whose access to education was impaired due to defective ed- ucational policies and the inefficiency of public services.

Of the researched events, $71.6 \%$ were caused by deliberately caused events and $27.4 \%$ by accidents, with $18.5 \%$ caused by accidents involving motorcycles.

With regard to LTAs, our findings agree with the majority of studies, in which the most frequent accidents were those involving motorcyclists $^{14,19-22}$. The inverse result was found in the study by Miranda et al. ${ }^{13}$, who also evaluated secondary documents, albeit by surveying health services.

The major increase in the number of motorcycles in the streets of Brazilian cities, without the due care for mobility in the streets or for the 
specific nature of their presence has not received due attention from the public authorities. On account of this, the authors reached rather pessimistic ${ }^{23}$ conclusions regarding the trend towards increased violence and deaths in road accidents within Brazil.

In cases involving motorcyclists, the characteristics of the individual were similar to those encountered in other studies ${ }^{1,15}$. The use of motorcycles as a means of transportation has increased considerably and rapidly throughout the country, in particular, in the municipality forming the object of the study, with a fleet of over 40,000 motocycles ${ }^{7}$.

We highlight the differences which may occur when we observe data for treatment at forensic medical and dental services, in which the individual claims his/her citizen's rights or in health services, in which the aim is to remedy injury to health.

Within the studied municipality, no study has been carried out on a forensic service for mortality data due to LTA or even to aggression, although a study was carried out within hospitals, which evaluated facial trauma suffered by women due to violent and non-violent mechanisms, the most predominant cause of which were falls from their own height ${ }^{24}$, coinciding with the study by Rodrigues et al. ${ }^{25}$ which arrived at similar findings.

Working days accounted for $65 \%$ of events, with $35.1 \%$ occurring at night. Considering the daily average, however, the frequency of incidents at weekends ( $16.5 \%$ per day) was greater than on working days ( $13.0 \%$ per day). The concentration of events may occur in space, in time or both. Works were published which examined the detection of clusters in the area of epidemiology, demonstrating the importance of using this methodology for elucidating these problems ${ }^{26}$.

The immediate consequences of the findings highlighted the risk of situations of violence in specific groups, the most applicable aspect of which is the identification of clusters. This technique allows for the clear identification of groups within the city which should form the object of public policies. A "focused" action will permit a greater degree of rationality in adopting programs and strategies for controlling health problems ${ }^{27}$.

Most trauma occurred to different regions of the body (63.6\%) and affected soft tissue (74.2\%), coinciding with the studies by Santos et al. ${ }^{15}$, Silva et al. ${ }^{28}$ and Costa et al..$^{24}$.

On using multiple correspondence analysis, three groups were identified with distinct pro- files. A first group consisting of young women (aged 20 to 29), who were single or separated, economically inactive (unemployed or who did not work), who had completed primary education and who suffered aggression, with facial injuries to soft tissues, in events which occurred in the evening/early morning at weekends.

It was found that at the time of completion of the report, the majority of women forming this group were economically inactive and had completed primary education, with this coinciding with the studies by Silva et al. ${ }^{28}$ and Macedo et al. ${ }^{29}$.

The average age of these victims coincided with the results of the study carried out by Magalhães et al. ${ }^{18}$, in Rio Branco (Acre State), but did not coincide with the study carried out by Silva et al..$^{28}$ in Recife (Pernambuco State). Recent studies ${ }^{18.28 .30}$ have highlighted that in cases of interpersonal aggression against women, single women were the most affected.

The second cluster consisted of adult men (aged 30 to 59), who were married, employed or self-employed and uneducated, who suffered bodily trauma with simple and multiple fractures deriving from land-based transportation accidents involving cars and occurring during the morning and on working days.

The vulnerability and risks to men continued to be greater compared to women, although among women, the highest frequency was that related to interpersonal gender relations ${ }^{30,31}$.

This violent behavior among males is probably the consequence of greater male exposure, with social and cultural origins, which caused men to assume greater risks of exposure to risky situations, such as driving vehicles at higher speed, more risky maneuvers, use of alcohol, etc., in addition to them involving themselves in situations such as fights, arguments and aggres$\operatorname{sion}^{32,33}$.

There was also a third group, consisting of men, who were widowers and pensioners, who were run over at undetermined times. These results are corroborated by the findings of the study by Alves $^{34}$ on the sex variable, in which males were a higher proportion of victims of road accidents.

Studies ${ }^{21,35}$ on mortality due to external causes in individuals aged over 60 within Brazil consider that being run over forms the most frequent cause of death in this age group. According to these authors, being hit by a vehicle is considered as one of the most violent accidents, with an absolutely unequal impact, which may cause serious injury, even when the vehicles are travelling 
at low speed, with the greater physical vulnerability of this age group making these even more lethal.

A limitation of the analysis of this study is due to the fact that it used an intentional sample and secondary data obtained from forensic medical and dental services, often with incomplete or poorly described reports, with the results valid for the victims treated at this location.

We also acknowledge that this study only offers a specific perspective on reality regarding accidents and aggression in a medium-size municipality, since it merely reveals data on non-fatal victims.

This study permits the display of the characteristics of these events and of their victims, which did not exist for a medium-sized municipality, since they only reveal data on non-fatal victims. We cannot make inferences for all of the victims in the city, since not everyone contacted these services.

This study permitted a display of the characteristics of these events and of their victims, which did not exist for a medium-sized municipality and which may make a substantial contribution to monitoring events and to the planning of health actions, aiding in the construction of an integrated health monitoring system, which interconnects police stations, forensic services and emergency hospitals. The events were characterized by a large number of victims of aggression, followed by accidents involving motorcycles.

\section{Collaborations}

S d'Avila prepared the development of the study protocol, the design of the method, data analysis, interpretation of results and wrote the paper. AC Campos participated in data analysis, interpretation of results, contributed to the revision of the paper and approved the final version. GMS Cavalcante, CJP Silva e LM Nóbrega participated in the development of the study protocol, performed the data collection, contributed to the revision of the paper and approved the final version. EF Ferreira participated in the study protocol development, design method, analyzed the data, interpreted the results, and performed the critical review of paper for final approval.

\section{References}

1. Mello Jorge MHP, Koizumi M, Tono V. Causas Externas: $\mathrm{O}$ que são como afetam o setor saúde, sua medida e alguns subsídios para a sua prevenção. Rev Saúde 2007; 1(1):37-47.

2. Mascarenhas MDM, Monteiro RA, Sá NNB, Gonzaga LAA, Neves ACM, Roza DL, Silva MMA, Duarte EC, Malta DC. Epidemiologia das causas externas no Brasil: morbidade por acidentes e violências. In: Brasil. Ministério da Saúde (MS). Secretaria de Vigilância em Saúde. Departamento de Análise de Situação em Saúde. Saúde Brasil 2010 uma análise da situação de saúde e de evidências selecionadas de impacto de ações de vigilância em saúde. Brasília: MS; 2011. p. 203-223.

3. Souza ER, Ximenes LF, Alves F, Magalhães C, Bilate D, Szuchmacher AM Malaquias J. Avanços do conhecimento sobre causas externas no Brasil e no Mundo: enfoque quanti e qualitativo. In: Minayo MCS, Souza ER, organizadores. Violência sob o olhar da saúde: a infrapolítica da contemporaneidade brasileira. Rio de Janeiro: Fiocruz; 2003. p. 131-162.

4. Cocco M, Lopes MJM. Morbidade por causas externas em adolescentes de uma região do município de Porto Alegre. Rev Eletr Enf 2010; 12(1):89-97.

5. Oliveira LR, Mello-Jorge MHP. Análise epidemiológica das causas externas em unidades de urgência e emergência em Cuiabá/Mato Grosso. Rev Bras Epidemiol 2008; 11(3):420-430. 
6. Lima MVF, Silva RLP, Albuquerque NMG, Oliveira JSA, Cavalcante CAA, Macêdo MLAF. Perfil dos atendimentos por causas externas em hospital público. Rev Rene 2012; 13(1):36-43.

7. Instituto Brasileiro de Geografia e Estatística (IBGE). Primeiros resultados do Censo 2010. Rio de Janeiro: IBGE; 2012. [acessado 2014 jan 22]. Disponível em: http://www.censo2010.ibge.gov.br/dadosdivulgados/ Index.php?uf $=25$

8. Brasil. Ministério da Saúde (MS). Conselho Nacional de Saúde. Resolução no 196 de 10 de outubro de 1996. Diretrizes e Normas Regulamentadoras de Pesquisas Envolvendo Seres Humanos. Diário Oficial da União 1996; 16 out.

9. Mota JC, Vasconcelos AGG, Assis SG. Correspondence analysis: a method for classifying similar patterns of violence against women. Cad Saude Publica 2008; 24(6):1397-1406.

10. Mota JC, Vasconcelos AGG, Assis SG. Análise de correspondência como estratégia para descrição do perfil da mulher vítima do parceiro atendida em serviço especializado. Cien Saude Colet 2007; 12(3):799-809.

11. Hair JF, Black WC, Babin JB, Anderson RE, Tatham RL. Segmentation Analysis. In Multivariate Data Analysis. New Jersey: Prentice-Hall Copyright; 2009.

12. Maroco J, Garcia-Marques T. Qual a fiabilidade do alfa de Cronbach? Questões antigas e soluções modernas? Laboratório de Psicologia 2006; 4(1):65-90.

13. Miranda MIF, Delfino RK, Carvalho QH, Pinto CCP, Silva MC, Restier RB, Luna K. Morbimortalidade por causas externas - acidentes e violência - no município de Porto Velho, Rondônia. Enfermagem em Foco 2010; 1(3):119-123.

14. Oliveira LR, Mello-Jorge MHP. Análise epidemiológica das causas externas em unidades de urgência e emergência em Cuiabá/Mato Grosso. Rev Bras Epidemiol 2008; 11(3):420-430.

15. Santos JLG, Garlet ER, Figueira RB, Lima SBS, Prochnow AG. Acidentes e Violências: caracterização dos atendimentos no pronto-socorro de um hospital universitário. Saúde Soc 2008; 17(3):211-218.

16. Martins RT. Seguro DPVAT. Campinas: Servanda; 2008.

17. Confederação Nacional de Munícipios (CNM). Mapeamento de mortes por acidente de trânsito no Brasil. Brasília: CNM; 2009.

18. Magalhães AF, Lopes CM, Koifman RJ, Muniz PT. Prevalência de acidentes de trânsito autor-referidos em Rio Branco, Acre. Rev Saude Publica 2011; 45(4):738744.

19. Mesquita Filho M, Mello-Jorge MHP. Características da morbidade por causas externas em serviço de urgência. Rev Bras Epidemiol 2007; 10(4):679-691.

20. Anjos KC, Evangelista MRB, Silva JS, Zumiotti AV. Paciente vítima de violência no trânsito: Análise do perfil socioeconômico, Características do acidente e intervenção do serviço social na emergência. Acta ortop. bras. 2007; 15(5):262-266.

21. Marín-León L, Belon AP, Barros MBA, Almeida SDM, Restitutti MC. Tendência dos acidentes de trânsito em Campinas, São Paulo, Brasil: importância crescente dos motociclistas. Cad Saude Publica 2012; 28(1):39-51.

22. Hashim H, Iqba S. Motorcycle accident is the main cause of maxillofacial injuries in the Penang Mainland, Malaysia. Dent Traumatol 2011; 27(1):19-22.
23. Minayo MCS. Morre menos quem morre no trânsito? Cien Saude Colet 2012; 17(9):2237-2238.

24. Costa MCF, Cavalcante GMS, Nóbrega LM, Oliveira PAP, Cavalcante JR, d'Avila S. Traumatismos faciais em mulheres por mecanismos violentos e não violentos. Braz J Otorhinolaryngol 2014; 80(3):196-201.

25. Rodrigues CS, Malta DC, Godinho T, Mascarenhas MDM, Silva MMA, Silva RE. Acidentes e violências entre mulheres atendidas em Serviços de Emergência Sentinela - Brasil, 2009. Cien Saude Colet 2012; 17(9):2319-2329.

26. Kronbauer JFD, Meneghel S. Perfil da violência de gênero perpetrada por companheiro. Rev Saude Publica 2005; 39(5):695-701.

27. Beato Filho CC, Assunção RM, Silva BFA, Marinho FC, Reis IA, Almeida MC. Conglomerados de homicídios e o tráfico de drogas em Belo Horizonte, Minas Gerais, Brasil, de 1995 a 1999. Cad Saude Publica 2001; 17(5):1163-1171.

28. Silva MA, Falbo-Neto GH, Figueiroa JN, Cabral-Filho JE. Violence against women: prevalence and associated factors in patients attending a public healthcare service in the Northeast of Brazil. Cad Saude Publica 2010; 26(2):264-272.

29. Macedo JLS, Camargo LM, Almeida PF, Rosa SC. Perfil epidemiológico do trauma de face dos pacientes atendidos no pronto socorro de um hospital público. Rev Col Bras Cir 2008; 35(1):9-13.

30. Rezende EJC, Araújo TM, Moraes MAS, Santana JSS, Radicchi R. Lesões buco-dentais em mulheres em situação de violência: um estudo piloto de casos periciados no IML de Belo Horizonte, MG. Rev Bras Epidemiol 2007; 10(2):202-214.

31. Weizmann-Henelius G, Viemero V, Eronen M. The violent female perpetrator and her victim. Forensic Sci Int 2003; 133(3):197-203.

32. Mann RE, Stoduto G, Vingilis E, Asbridge M, Wickens CM, Ialomiteanu A, Sharpley J, Smart RG. Alcohol and driving factors in collision risk. Accid Anal Prev 2010; 42(6):1538-1544.

33. Moan IS, Rise J. Predicting intentions not to "drink and drive" using an extended version of the theory of planned behaviour. Accid Anal Prev 2011; 43(4):1378-1384.

34. Alves EF. Características dos acidentes de trânsito com vítimas de atropelamento no município de Maringá PR, 2005/2008. Saúde e pesquisa. 2010; 3(1):25-32.

35. Gawryszewski VP, Coelho HM, Scarpelini S, Zan R, Mello-Jorge MHP, Rodrigues EMS. Perfil dos atendimentos a acidentes de transporte terrestre por serviços de emergência em São Paulo. 2005. Rev Saude Publica 2009; 43(2):275-282.

Article submitted 14/04/2014

Approved 13/09/2014

Final version submitted 15/09/2014 